\title{
ANALISIS POLA KONSUMSI PANGAN DI PROPINSI SULAWESI UTARA
}

\author{
${ }^{1)}$ Gabriel H. Joseph \\ ${ }^{1)}$ Balai Pengkajian Teknologi Pertanian (BPTP) Sulawesi Utara \\ Jl. Kampus Pertanian Kalasey, Sulut \\ email: gabyjoseph@gmail.co.id
}

\begin{abstract}
ABSTRAK
Keragaman pola konsumsi pangan masyarakat pada masing-masing daerah berbeda-beda, tergantung dari potensi daerah dan struktur budaya masyarakat. Pola konsumsi masyarakat Indonesia umumnya masih didominasi oleh padi-padian terutama beras, dan sebagai upaya untuk mengurangi ketergantungan masyarakat pada beras maka perlu menggali potensi lokal yang berbasis non beras untuk memenuhi kebutuhan.Penelitian bertujuan menganalisis kontribusi konsumsi energi dan protein dari berbagai kelompok pangan, menganalisis proporsi sumbangan energi dari beras terhadap total konsumsi energy, dan menganalisis hubungan antara aspek sosial ekonomi keluarga terhadap keaneka ragaman konsumsi pangan (skor PPH).Tingkat konsumsi pangan dikumpulkan dengan metode Recall kemudian dikonversikan dengan ke dalam bentuk zat gizi dengan menggunakan Daftar Komposisi Bahan Makanan (DKBM). Data primer yang lain juga dikumpulkan melalui wawancara langsung dengan informan menggunakan alat bantu kuesioner secara terstruktur. Data sekunder diperoleh dari dari dokumen, laporan, catatan resmi dari instansi terkait sesuai dengan jenis data yang diperlukan. Diperoleh konsumsi pangan masyarakat Sulawesi Utara berada diatas Angka Kecukupan Energi Ideal sebesar 2.000 $\mathrm{kkal} / \mathrm{kapita} / \mathrm{hari}$, yakni sebesar $2.021 \mathrm{kkal}$ perkapita perhari., termasuk dalam kategori normal(90$<120 \%$ AKE/G), sedangkan Angka Kecukupan Protein mencapai 110,5\% yakni 57,5 g/kapita/hari berada diatas angka rata-rata nasional 50,1 g/kapita/hari. Kelompok Pangan padi-padian menyumbangkan energi paling besar yaitu 1166,9 kkal perkapita per hari (58,3\% dari angka kecukupan energi), diikuti Minyak dan Lemak 256,8 kkal ( 12,8 \%), Pangan Hewani 212,9 kkal $(10,6 \%)$, sayur dan buah 171,0 kkal (8,5 \%) dan Umbi-umbian sebesar 64,5 kkal (3,2 \%), sedangkan Kelompok Pangan Buah/Biji Berminyak dan Kelompok Pangan Lain-lain menyumbangkan energi paling kecil, masing-masing yaitu 28,2 kkal ( $1,4 \%)$, dan 27,5 kkal $(1,4 \%)$. Pola Konsumsi Pangan masyarakat masih belum beragam, bergizi dan seimbang. Hal ini ditunjukkan dari skor PPH baru sebesar 89,8 atau kurang dari skor PPH ideal sebesar 100. Aspek sosial ekonomi yang meliputi tingkat pendidikan, jumlah anggota rumah tangga, dan pendapatan rumah tangga menunjukkan tidak terdapat hubungan yang signifikan terhadap tingkat kecukupan gizi (AKE dan AKP). Disarankan perlu upaya promosi kesehatan khususnya mengkonsumsi makanan yang beragam, berimbang, dan bergizi serta mengembangkan sumber karbohidrat umbiumbian lokal yang potensial, strategis, dan prospektf dalam meningkatkan skor PPH.
\end{abstract}

Kata kunci : konsumsi pangan, angka kecukupan energi (AKE), angkakecukupan protein (AKP, PPH)

\section{ANALYSIS OF FOOD CONSUMTION IN NORTH SULAWESI PROVINCE}

\begin{abstract}
The diversity of food consumption patterns of society in each region varies, depending on the potential of the region and the cultural structure of society. Indonesian people consumption patterns are still dominated by grains, especially rice, and in order to reduce the dependence of the community on rice, it is necessary to explore the non-rice based local potentials to meet the needs. The study aims to analyze the contribution of energy and protein consumption from various food groups, analyze the proportion of energy contribution from rice to total energy consumption, and analyze the relationship between the socio-economic aspect of the family to the diversity of food
\end{abstract}


consumption (PPH score). Food consumption level collected by Recall method then converted into nutrient form using the Food Composition List (DKBM). The other primary data were also collected through interviewees a direct with the informant using the tool questionnaire structured. Secondary data obtained from the documents, reports, official records of relevant agencies in accordance with the type of data required. The consumption of North Sulawesi people's food is above the Ideal Energy Sufficiency Level of 2,000 kcal / capita / day, that is equal to 2,021 kcal per capita per day, including in normal category (90 120\% AKE / G), while Protein Sufficiency Rate reach $110,5 \%$ ie $57,5 \mathrm{~g} /$ day capital is above national average 50,1 g / capita / hari.Group Grains group donated the most energy, namely $1166.9 \mathrm{kcal}$ per capita per day (58.3 from the energy sufficiency), followed by Oil and Fat $256.8 \mathrm{kcal}(12.8 \%)$ Hewani Food 212, 9 kcal $(10.6 \%)$, vegetables and fruit $171.0 \mathrm{kcal}(8.5 \%)$ and tubers of $64.5 \mathrm{kcal}(3.2 \%)$, while the Group of Oily Fruits / Grains and Food Groups Others contribute the least energy, each of which is 28.2 kcal (1.4\%), and $27.5 \mathrm{kcal}(1.4 \%)$. Community Food Consumption Pattern is still not diverse, nutritious and balanced. This is demonstrated by the new PPH score of 89.8 or less than the ideal PPH score of 100. Socio-economic aspects including education level, number of household members, and household income indicate no significant relationship to nutritional adequacy level (AKE and AKP). Suggetions that can be recommended is the need for health promotion efforts in partiqular consume diverse, balanced and nutritions foods, also develop the potential, strategic and perfective root carbohydrate sources in order to increase the PPH score.

Keywords: food consumption, energy adequacylevel (AKE), protein adequacy level (AKP), desirable dietary pattern $(\mathrm{PPH})$

\section{PENDAHULUAN}

Konsep ketahanan pangan yang melahirkan formulasi pangan yang beragam berimbang dan bergizi bertujuan untuk memenuhi pangan secara nasional dan lokal secara sistimatis dan berkelanjutan (Suryana, 2012). Hal ini sangat mendasar dan esensial karena pangan merupakan komoditas penting dan strategis sebagai kebutuhan pokok manusia yang pemenuhannya menjadi hak asasi setiap rakyat Indonesia sebagaimana dinyatakan dalam UU N0.7 Tahun 1996.Faktor penentumutu pangan adalah keanekaragaman (diversifikasi) jenis pangan, keseimbangan gizidan keamanan pangan (Balitbang Pertanian,2012; Hariyadi dkk. 2006; BKP, 2012a).

Indonesia kaya keanekaragaman sumber bahan pangan, baik nabati maupun hewani guna memenuhi pemenuhan gizi untuk kesehatan masyarakat.Umumnya masyarakat Indonesia mengkonsumsi beras sebagai pangan pokok sebagai sumber karbohidrat, sehingga ketergantungan pada beras semakin besar (Calverley, 1994; Hardinsyah dkk. 2012).Diversifikasi pangan merupakan hal yang sangat penting karena dalam lingkup nasional, pengurangan konsumsi beras akan memberikan dampak positif terhadap ketergantungan impor beras, diversifikasi (konsumsi) pangan akan mengubah alokasi sumberdaya kearah yang efisien, fleksibel dan stabil jika didukung dengan pemanfaatan potensi lokal, dan dari segi nutrisi dapat mewujudkan Pola Pangan Harapan (Ariani, 2006; Budiarjo, 2008; Broto, 2012).

Di Indonesia rata-rata konsumsi beras perkapita per tahun hampir mencapai $140 \mathrm{~kg}$,dua kali lebih besar dibanding konsumsi masyarakat Eropa dan Amerika(Suryana, 2012). Akselerasi penurunan tingkat konsumsi beras dengan menerapkan diversifikasi pangan secara sistimatik dan berkelanjutan diprediksi dapat turun sebesar 1 sampai 2 persen setiap tahun (BKP, 2012b).Menurut Peraturan Pemerintah Republik Indonesia No. 68 Tahun 2002 tentang ketahanan pangan, disebutkan bahwa ketahanan pangan adalah kondisi terpenuhinya pangan bagi rumah tangga yang tercermin dari tersedianya pangan yang cukup, baik jumlah maupun mutunya, aman, merata dan terjangkau(Suryana,2012;BalitbangPertanian ,2012;BKP,2012b; Broto,2012).

Pola konsumsi pangan pada masyarakat Sulawesi Utara bergeser secara dinamis, dipengaruhi oleh banyak faktor seperti kondisi sosial, budaya, ekonomi,preferensi dan ketersediaan 
(BPS,2010a;Dinas Pertanian,2015). Hasil pengamatan Model Kawasan Rumah Pangan Lestari (MKRPL) di 4 lokasi yakni Bitung, Minahasa Utara, Minahasa Selatan, dan Minahasa Tenggara menunjukan bahwa umumnya masyarakat mengkonsumsi sumber energi tertinggi berasal dari kelompok padi-padian sebesar2021 kkal/kapita/hari (Joseph,2015). Angka ini melampaui diatas rata-rata angka kecukupan energi (AKE) ideal yaitu sebesar 2000 kkal/kapita/hari (WNPG,2004), sedangkan nilai skor Pola Pangan Harapan(PPH) masih relative rendah yakni kurang dari skor 90dibanding nilai skor ideal 100 (Joseph,2015. Berdasarkan uraian diatas, dilakukan kajian analisis konsumsi pangan di Provinsi Sulawesi Utara, yang bertujuan (1) mendapatkan informasi tentang konsumsi energi dan zat gizi, (2) bagaimanapola konsumsi pangan masyarakat Sulawesi Utara dan (3) mencari sumber pangan lokal pengganti beras.

\section{BAHAN DAN METODE}

Pelaksanaan kegiatan survey selama 2 minggu pada bulan September sampai Oktober 2017, di 4 lokasi yakni Kabupaten Minahasa, Kabupaten Kepulauan Sangihe, Kota Kotamobagu dan Kota Manado Provinsi Sulawesi Utara.Masing-masing Kabupaten/Kota diwakili 11 Kecamatan, dan setiap kecamatan diwakili 3 desa, setiap desa dipilihsecara acak sebanyak 10informan sehingga total informan 330 .

Jenis data yang dikumpulkan terdiri dari data primer dan data sekunder. Data primer meliputi status ekonomi keluarga, anggotakeluarga, pendidikan isteri dan suami, pendidikan non formal/pelatihan/kursus yang pernah diikuti, pembinaan di bidang pangan gizi dan kesehatan, umur isteri dan suami, konsumsi pangan, pengetahuan gizi dan pangan, sikap gizi dan pangan. Data sekunder diambil dari BPS Sulawesi Utara meliputi: Keadaan umum wilayah penelitian (fasilitas sarana perekonomian, kesehatan, pendidikan, jenis pekerjaan penduduk), program yang berkaitan dengan diversifikasi konsumsi pangan untuk wilayah yang bersangkutan.

\section{Teknik Pemilihan dan Penentuan Informan}

Informan pada penelitian ini adalah keluarga anggota Kelompok Wanita Tani (KWT) yang mengikuti program Model Kawasan Rumah Pangan Lestari di setiap lokasi Kabupaten Kota. Pemilihan contoh didasarkan metode sampling purposive.Sugiyono, 2008 menyatakan bahwa sampling purposive adalah teknikpenentuan sampel dengan pertimbangan tertentu.Karena dalam penelitian ini pertimbangan yang diambil adalah informan pada Kelompok Wanita Tani (KWT) yang mengikuti kegiatan Model Kawasan Rumah Pangan Lestari (MKRPL) di Sulawesi Utara dengan pengelompokan adalah tingkat pendidikan maka sample minilmal dalam tiap kategori adalah 30.Jumlah sampel yang di butuhkan dalam penelitian menggunakan rumus Slovin sebagai berikut:

Dimana,

$$
n=\frac{N}{1+\left(N e^{2}\right)}
$$

n: jumlah sampel

$\mathrm{N}:$ jumlah populasi

E:tingkat toleransi kesalahan(error tolerance)

Tahapan pemilihan informan sebagai berikut:

Pengelompokkan berdasarkan tingkat pendidikan sekolah dasar (SD), sekolah menengah pertama (SMP), sekolah menengah atas (SLTA) dan perguruan tinggi. Total informan sebanyak 330 dengan uraian sebagai berikut:

1. Kabupaten Minahasa, 3 kecamatan yakni Tombulu, Tombariri, dan Kawangkoan.

2. Kabupaten kepulauan Sangihe, 3 kecamatan yakni Tahuna, Tahuna Timur, dan Tabukan Selatan.

3. Kota Kotamobagu, 2 kecamatan yakni Kotamobagu Selatan, dan Kotamobagu Barat.

4. Kota Manado, 3 kecamatan yakni Mapanget, Bunaken , dan Paal Dua.

Setiap kecamatan diwakili 3 desa, dengan demikian rincian pembagian informan dari 11 lokasi survey sebagai berikut:

1.Kabupaten Minahasa 90 informan. 
2. Kabupaten kepulauan Sangihe 90 informan.

3. Kota Kotamobagu 60 informan.

4. Kota Manado 90 informan.

\section{Metode Pengumpulan dan Pengukuran} Data

$\begin{array}{ccc}\text { Tingkat } & \text { konsumsi } & \text { pangan } \\ \text { dikumpulkan dengan metode } & \text { Recall }\end{array}$ kemudian dikonversikan dengan ke dalam bentuk zat gizi dengan menggunakan Daftar Komposisi Bahan Makanan (DKBM). Data primer yang lain juga dikumpulkan melalui wawancara langsung dengan responden dengan alat bantu kuesioner secara terstruktur. Data sekunder diperoleh dari dari dokumen, laporan, catatan resmi dari instansi terkait sesuai dengan jenis data yang diperlukan.

\section{Pengolahan dan Analisis Data}

a. Keadaan umum wilayah akan diolah dan disajikan dalam bentuk diskriptif.

b. Prasarana perekonomian, pendidikan, kesehatan dan pekerjaan dibuat presentase dan disajikan secara tabel dan dinarasikan secara diskriptif.

c. Karakteristik sosial ekonomi keluarga akan dibuat rata-rata, nilai maksimum dan minimum dikelompokkan yang selanjutnya dipresentasekan, disajikan dalam bentuk table.

Data konsumsi pangan akan diolah untuk mengetahui:

1. Tingkat konsumsi energi dan protein dinyatakan sebagai ratio antara konsumsi energi dan protein dengan kecukupan dinyatakan dalam persen. Secara matematis dirumuskan sebagai berikut :

Tingkat konsumsi energi atau protein = TKGi $=(K G i:$ AKGi $) \times 100 \%$

Ket :

$\mathrm{KGi}=$ konsumsi energi atau protein

$\mathrm{AKGi}=$ Angka kecukupan energi atau protein

2. Tingkat ketergantungan pada beras diartikan sebagai proporsisumbangan energi beras terhadap total konsumsi energi yang dinyatakan dalam persen dan tingkat keaneka ragaman konsumsi pangan. Secara matematis dirumuskan sebagai berikut:

$\mathrm{TKB}=(\mathrm{KEB}: \mathrm{KEP}) \times 100 \%$

Ket :

$\mathrm{TKB}=$ tingkat ketergantungan pada beras
$\mathrm{KEB}=$ konsumsi energi dari beras

$\mathrm{KEP}=$ total konsumsi energi

Selanjutnya dibuat rata-rata, nilai maksimum dan minimum, dikelompokkan, disajikan dalam bentuk tabel dan gambar. Kemudian dilakukan uji Anova bila ada perbedaan nyata dan dilanjutkan dengan uji beda lanjut (LSD).

Pengetahuan gizi dan pangan, sikap dan perilaku terhadap pemilihan pangan. Dibuat rata-rata, nilai maksimum dan minimum dikelompokkanyang selanjutnya dipresentasekan, disajikan dalam bentuk tabel.

Untuk melihat pengaruh aspeksosial ekonomi terhadap keanekaragamankonsumsi pangan digunakan regresi Persamaan

$$
\mathrm{Yi}=\beta \mathrm{o}+\beta_{\mathrm{i}-\mathrm{n}} \mathrm{X}_{\mathrm{i}-\mathrm{n}}+\varepsilon
$$

Keterangan:

$\mathrm{Yi}=$ Keanekaragaman konsumsi pangan (skor PPH)

$\mathrm{X} 1=$ Pendapatan keluarga dalam bulan (Rp/bulan)

$\mathrm{X} 2=$ Pengeluaran pangan $(\mathrm{Rp} / \mathrm{bulan})$

$\mathrm{X} 3=$ Pendidikan Ibu (Tahun )

$\mathrm{X} 4=$ Pendidikan Bapak (Tahun )

$\mathrm{X} 5=$ Besar keluarga (jiwa)

X6= Pengetahuan Gizi (skor) $\varepsilon=$ error

$\beta o=$ Intercept

$\beta \mathrm{i}-\mathrm{n}=$ Regression coefficient

\section{HASIL DAN PEMBAHASAN}

\section{Keadaan Umum Wilayah}

Berdasarkan posisi geografisnya, Provinsi Sulawesi Utara terletak di jazirah utara Pulau Sulawesi dan merupakan salah satu dari tiga provinsi di Indonesia yang terletak di sebelah utara garis khatulistiwa. Dua provinsi lainnya adalah Provinsi Sumatera Utara dan Provinsi Daerah Istimewa Aceh. Dilihat dari letak geografis Provinsi Sulawesi Utara terletak pada $0^{\circ} \mathrm{LU}$ - $3^{\circ} \mathrm{LU}$ dan $123^{\circ} \mathrm{BT}-126^{\circ} \mathrm{BT}$ (Gambar 1).

Sulawesi Utara merupakan sebuah provinsi yang beribukota Manado, mempunyai 15 Kabupaten/kota yakni Kabupaten Bolaang Mongondow, Kabupaten Bolaang Mongondow Selatan, Kabupaten Bolaang Mongondow Timur, Kabupaten Bolaang Mongondow Utara, 
Kabupaten Kepulauan Sangihe, Kabupaten Kepulauan Siau Tagulandang Biaro, Kabupaten Kepulauan Talaud, Kabupaten Minahasa, Kabupaten Minahasa Selatan, Kabupaten Minahasa Tenggara, Kabupaten Minahasa Utara, Kota Bitung, Kota Kotamobagu, Kota Manado dan Kota Tomohon. Wilayah administrasi pemerintahan Provinsi Sulawesi Utara terdiri dari 11 daerah kabupaten dan empat daerah kota. Berdasarkan keadaan tahun 2015 terdapat 167 kecamatan dan 1.840 desa/kelurahan.

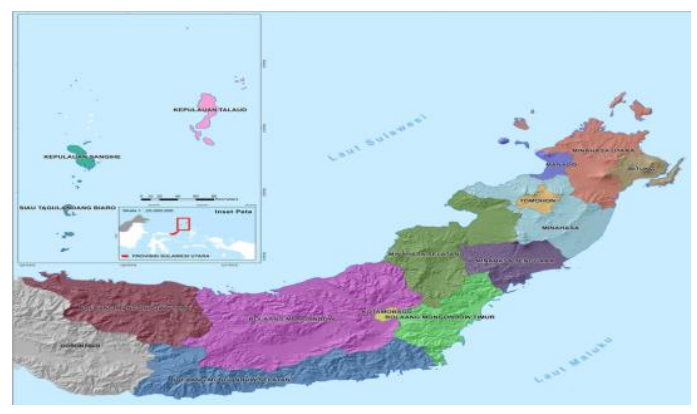

Gambar 1. Peta wilayah Provinsi Sulawesi Utara

\section{Pengeluaran Kelompok Makanan Menurut Komoditas}

Pengeluaran rata-rata per kapitaadalah biaya yang dikeluarkan untuk konsumsi semua anggota rumah tangga selama sebulan baik yang berasal dari pembelian, pemberian maupun produksi sendiri dibagi dengan banyaknya anggota rumah tangga dalam rumah tangga tersebut. Secara umum, tingkat ketersediaan pangan ditinjau dari kecukupan gizi, yang mana angka kecukupan gizi yang dianjurkan pada Widyakarya Pangan dan Gizi ke VIII (2004) adalah sekitar $2.000 \mathrm{kkal} / \mathrm{kapita} / \mathrm{hari}$ dan untuk protein sekitar 52 gram/kapita/hari. Ketersediaan kalori perkapita per hari pada tahun 2015 sebesar 4.076 kkal dan untuk protein sebesar 113,26 gram. Jika dibandingkan dengan standar kecukupan pangan di atas, maka angka kecukupan pangan Sulawesi Utara pada tahun tersebut, sudah cukup dari yang disarankan.
Tabel 1. Karakteristik Rumah Tangga

\begin{tabular}{|c|c|}
\hline Variabel & $\%$ \\
\hline \multicolumn{2}{|l|}{ Tingkat pendidikan KK } \\
\hline Tidak pernah sekolah & - \\
\hline Tidak tamat/tamat SD & 10.8 \\
\hline Tamat SLTP & 26.2 \\
\hline Tamat SLTA & 46.8 \\
\hline Tamat Perguruan Tinggi & 16.2 \\
\hline Total & 100.0 \\
\hline \multicolumn{2}{|l|}{ Tingkat pendidikan ibu } \\
\hline Tidak pernah sekolah & - \\
\hline Tidak tamat/tamat SD & 15.2 \\
\hline Tamat SLTP & 28.2 \\
\hline Tamat SLTA & 40.8 \\
\hline Tamat Perguruan Tinggi & 15.8 \\
\hline Total & 100.0 \\
\hline \multicolumn{2}{|l|}{ Pekerjaan KK } \\
\hline Tidak bekerja & 1.5 \\
\hline TNI/Polri/PNS/Pegawai & 19.8 \\
\hline Wiraswasta/layan jasa/dagang & 62.2 \\
\hline Petani/nelayan/buruh & 12.3 \\
\hline Lainnya & 4.2 \\
\hline Total & 100.0 \\
\hline \multicolumn{2}{|l|}{ Pekerjaan iburumah tangga } \\
\hline Tidak bekerja & 10.1 \\
\hline TNI/Polri/PNS/Pegawai & 5.8 \\
\hline Wiraswasta/layan jasa/dagang & 77.8 \\
\hline Petani/nelayan/buruh & 2.1 \\
\hline Lainnya & 4.2 \\
\hline Total & 100.0 \\
\hline \multicolumn{2}{|l|}{ Besar keluarga } \\
\hline$\leq 4$ anggota keluarga (kecil) & 95.8 \\
\hline 5 - 7 anggota keluarga (sedang) & 4.2 \\
\hline > 7 anggota keluarga (besar) & - \\
\hline Total & 100.0 \\
\hline $\begin{array}{l}\text { Pengeluaran } \\
\text { (Rp/kap/bln) }\end{array}$ & \\
\hline Pengeluaran pangan & 426.278 \\
\hline Pengeluaran non pangan & 394.149 \\
\hline Pengeluaran total & 810.427 \\
\hline
\end{tabular}

Karakteristik Sosial Ekonomi

Format karakteristik rumah tanggameliputi tingkat pendidikan kepala keluarga,tingkat pendidikan ibu rumah tangga, pekerjaan kepala keluarga, pekerjaan iburumah tangga, besar keluarga, pengeluaran rumah tangga dan proporsipengeluaran pangan terhadap 
pengeluaran total rumah tangga. Karakteristiksosial ekonomi keluarga disajikan pada Tabel 1.

Tabel 1 memperlihatkan bahwa sebagian besar $(46.8 \%)$ tingkat pendidikan kepalakeluarga (KK) adalah tamat SLTA, begitu pula tingkat pendidikan ibu rumahtangga sebagian besar $(40.8 \%)$ adalah tamat SLTA. Tingkat pendidikan orang tua merupakan salah satu faktor yang berpengaruh terhadap pola asuh anak termasuk pemberian makan. Latar belakang pendidikan ibu juga berpengaruh terhadap perilaku ibu dalam mengelola rumah tangga, terutama dalam pemilihan makanan seharihari yang berperan penting dalam menentukan status gizi balita dan keluarga (Damanik dkk..2010). Sebagian besar pekerjaan kepala keluarga adalah wiraswasta yaitu $62.2 \%$ namun masih terdapat $1.5 \%$ kepala keluarga yang tidak berkerja, sedangkan untuk ibu rumah tangga terdapat $77.8 \%$ berprofesi sebagai wiraswasta namun sebagian besar (10.1\%) tidak bekerja.

Ada kecenderungan bahwa jenis pekerjaan yang dilakukan mempengaruhi besar pendapatan yang diterima individu.Sebagian besar rumah tangga contoh (95.8\%) termasuk keluarga kecil, hanya $4.2 \%$ keluarga sedang. Tanziha dan Herdiana (2009) melaporkan bahwa jumlah anggota keluarga mempengaruhi kebiasan makan dan gizi rumah tangga.Pengeluaran rata-rata rumah tangga perkapita perbulan adalah sebesar Rp810.427, dimana pengeluaran rata-rata untuk pangan adalah sebesar Rp 426.278 dari total pengeluaran dan pengeluaran rata-rata untuk non pangan Rp394.149/. Berdasarkan proporsi pengeluaran pangan rumatangga, sebagianbesar rumah tangga memiliki proporsi pengeluaran pangan $<60 \%$ sehingga termasuk dalam rumah tangga dengan kategori "tahan panganKerentanan suatu rumah tangga terhadap akses pangan tercermin dalamproporsi pengeluaran untuk membeli makanan.Rumah tangga disebut memilikiketerjangkauan pangan yang baik apabila pendapatan perkapitanya berada diatas garis kemiskinan dan proporsi pengeluaran pangannya kurang dari 60\% pengeluaran riil (Manesa 2008).

Tabel 2.Komposisi Pangan Beragam, Bergizi dan Seimbang (per kapita per hari) sesuai Susunan Pola Pangan Harapan Nasional

\begin{tabular}{llllll}
\hline No & Kelompok Pangan & $\begin{array}{l}\text { BBerat } \\
(((\text { gram })\end{array}$ & $\begin{array}{l}\text { EEnergi } \\
(((\mathrm{kkal})\end{array}$ & $\% \%$ AKE/G & $\begin{array}{l}\text { SksSkor } \\
\text { PPPPH }\end{array}$ \\
\hline 1 & Padi-padian & 275 & 1000 & 50,0 & 25,0 \\
2 & Umbi-umbian & 100 & 120 & 6,0 & 2,5 \\
3 & Pangan Hewani & 150 & 240 & 12,0 & 24,0 \\
4 & Minyak dan Lemak & 20 & 200 & 10,0 & 5,0 \\
5 & Buah/biji berminyak & 10 & 60 & 3,0 & 1,0 \\
6 & Kacang-kacangan & 35 & 100 & 5,0 & 10,0 \\
7 & Gula & 30 & 100 & 5,0 & 2,5 \\
8 & Sayur dan Buah & 250 & 120 & 6,0 & 30,0 \\
9 & Lain-lain & - & 60 & 3,0 & 0,0 \\
\hline T o t a I & & $\mathbf{2 . 0 0 0}$ & $\mathbf{1 0 0}$ & $\mathbf{1 0 0}$ \\
\hline
\end{tabular}

a) Defisit berat (<70\% AKE/G); b) Defisit sedang (70 - <80\% AKE/G);

c) Defisit ringan $(80-<90 \%$ AKE/G); d) Normal (90 - < $120 \%$ AKE/G);

e) Kelebihan (> $120 \% \mathrm{AKE} / \mathrm{G})$

Analisis Konsumsi PanganPola konsumsi pangan pada masyarakat Sulawesi Utara bergeser secara dinamis, dipengaruhi oleh banyak faktor seperti kondisi sosial, budaya, ekonomi, preferensi dan ketersediaan. Namun sebagaimana diamanatkan dalam
Peraturan Presiden No.22 Tahun 2009 tentang Kebijakan Percepatan Penganekaragaman Konsumsi Pangan Berbasis Sumber Daya Lokal, bahwa upaya penganekaragaman konsumsi pangan harus berbasis sumber pangan setempat atau 
pangan lokal. Pangan lokal sumber karbohdrat non beras yang berpeluang untuk dikembangkan di Sulawasi Utara antara lain umbi wongkai sayawu, bete putih, daluga, kolerea dan bete cabut serta pisang goroho.

Pengurangan konsumsi beras juga harus disertai dengan pengurangan konsumsi gandum/terigu yang seluruhnya diimpor. Konsumsi beras sebagai sumber karbohidrat dari kelompok padi-padian dapat disubsitusi dengan sumber karbohidrat dari pangan lokal kelompok padi-padian lain (penganekaragaman konsumsi secara horizontal) yang biasa dikonsumsi masyarakat berdasarkan kearifan lokal antara lain: jagung dan sorghum, Sedangkan untuk kelompok umbi-umbian komoditas yang dapat saling menggantikan yaitu ubi kayu, ubi jalar, talas, pisang, labu kuning, sagu dan sukun.

Setiap komoditi pada masingmasing kelompok bahan pangan diupayakan selalu ada dalam setiap menu makanan harian, sehingga kecukupan energi pada setiap individu dapat terpenuhi. Kecukupan energi pada setiap individu ini terlihat pada nilai PPHyang diharapkan dapat terus meningkat besarannya (Tabel 2) Peningkatan kualitas konsumsi pangan juga dapat dicapai melalui penganekaragaman pangan secara vertikal yaitu konsumsi aneka ragam jenis pangan sumber karbohidrat dan olahannya (jenis padi-padian: jagung dan olahannya, sorghum, dan jenis padi-padian lainnya), aneka pangan sumber protein dan olahannya (aneka pangan hewani dan aneka kacang-kacangan), serta aneka pangan sumber vitamin dan olahannya (beragam jenis sayur dan buah).

Norma gizi mengisyaratkan bahwa terdapat standar minimum jumlah makanan yangdibutuhkan seorang individu agar dapat hidup sehat dan aktif beraktivitas. Salahsatu ukuran kuantitas konsumsi pangan adalah jumlah konsumsi energi ataukonsumsi protein.Kuantitas konsumsi pangan ditinjau dari volume pangan yangdikonsumsi dan jumlah zat gizi yang dikandung dalam bahan pangan. Untuk menilai konsumsi pangan secara kuantitatif digunakan parameter TingkatKonsumsi Energi (TKE).

Keragaman pola konsumsi pangan dapat diuraikan sebagai berikut : a). Masyarakat Sulawesi Utara telah mengkonsumsi pangan dalam jumlah diatas Angka Kecukupan Energi Ideal sebesar $2.000 \mathrm{kkal} / \mathrm{kapita} / \mathrm{hari}$. Hal ini ditunjukkan dalam jumlah kalori/energi yang dikonsumsi yaitu sebesar 2.021 kkal perkapita perhari, jumlah tersebut mencapai $101.1 \%$ dari ratarata angka kecukupan energi ideal sebesar 2.000 kkal (WNPG 2004), sehingga bila dilihat dari klasifikasi tingkat konsumsi pangan masih termasuk dalam kategori normal(90-<120\%AKE/G) (Tabel 2).Hasil ini jauh lebih realistis dibanding 2 daerah yang terdapat di Jawa yakni Jateng dan DKI Jakarta yang berada dibawah angka 2000 kkal ( Anwar dan Hardiansyah 2014).

b). Kelompok Pangan padi-padian menyumbangkan energi paling besar yaitu 1166,9 kkal perkapita per hari $(58,3 \%$ dari angka kecukupan energi), diikuti Minyak dan Lemak 256,8 kkal ( $12,8 \%$ ), Pangan Hewani 212,9 kkal (10,6\%), sayur dan buah 171,0 kkal (8,5 \%) dan Umbi-umbian sebesar 64,5 kkal (3,2 \%), sedangkan Kelompok Pangan Buah/Biji Berminyak dan Kelompok Pangan Lain-lain menyumbangkan energi paling kecil, masing-masing yaitu 28,2 kkal (1,4\%), dan 27,5 kkal (1,4\%).

c). Konsumsi protein masyarakat Sulawesi Utara mencapai 57,5 Gram/Kapita/Hari. Jika dibandingkan dengan Angka Kecukupan Protein sebesar 52,0 Gram/Kapita/Hari maka Tingkat Konsumsi Protein telah mencapai 110,5 \% AKP. Angka ini masih diatas rararata nasional 50.1 g/kapita/hari (Anwar dan Hardiansyah, 2014). 
Tabel 3. Konsumsi Energi per Kelompok Pangan dan Skor PPH Berdasarkan Survey Pola Konsumsi Pangan di Provinsi Sulawesi Utara, Tahun 2015

\begin{tabular}{|c|c|c|c|c|c|c|c|c|c|}
\hline \multirow[b]{2}{*}{ No } & \multirow{2}{*}{$\begin{array}{l}\text { Kelompok } \\
\text { Pangan }\end{array}$} & \multicolumn{8}{|c|}{ Perhitungan Skor Pola Pangan Harapan (PPH) } \\
\hline & & Kkal & $\%$ & $\begin{array}{l}\% \\
\text { AKE*) }\end{array}$ & Bobot & $\begin{array}{l}\text { Skor } \\
\text { Aktual }\end{array}$ & $\begin{array}{l}\text { Skor } \\
\text { AKE }\end{array}$ & $\begin{array}{l}\text { Skor } \\
\text { Maks }\end{array}$ & $\begin{array}{l}\text { Skor } \\
\text { PPH }\end{array}$ \\
\hline 1. & Padi-padian & 1166,9 & 57,7 & 58,3 & 0,5 & 28,9 & 29,2 & 25,0 & 25,0 \\
\hline 2. & $\begin{array}{l}\text { Umbi- } \\
\text { umbian } \\
\text { Pangan }\end{array}$ & 64,5 & 3,2 & 3,2 & 0,5 & 1,6 & 1,6 & 2,5 & 1,6 \\
\hline 3. & $\begin{array}{l}\text { Hewani } \\
\text { Minyak dan }\end{array}$ & 212,9 & 10,5 & 10,6 & 2,0 & 21,1 & 21,3 & 24,0 & 21,3 \\
\hline 4. & $\begin{array}{l}\text { Lemak } \\
\text { Buah/Biji }\end{array}$ & 256,8 & 12,7 & 12,8 & 0,5 & 6,4 & 6,4 & 5,0 & 5,0 \\
\hline 5. & $\begin{array}{l}\text { Berminyak } \\
\text { Kacang- }\end{array}$ & 28,2 & 1,4 & 1,4 & 0,5 & 0,7 & 0,7 & 1,0 & 0,7 \\
\hline 6. & kacangan & 51,3 & 2,5 & 2,6 & 2,0 & 5,1 & 5,1 & 10,0 & 5,1 \\
\hline 7. & $\begin{array}{l}\text { Gula } \\
\text { Sayur dan }\end{array}$ & 42,0 & 2,1 & 2,1 & 0,5 & 1,0 & 1,0 & 2,5 & 1,0 \\
\hline 8. & Buah & 171,0 & 8,5 & 8,5 & 5,0 & 42,3 & 42,7 & 30,0 & 30,0 \\
\hline 9. & Lain-lain & 27,5 & 1,4 & 1,4 & 0,0 & 0,0 & 0,0 & 0,0 & $\mathbf{0 , 0}$ \\
\hline & Total & 2.021 & 100,0 & 101,1 & 11,5 & 107,0 & 108,1 & 100,0 & 89,8 \\
\hline
\end{tabular}

*) Angka Kecukupan Energi (AKE) : $2.000 \mathrm{Kkal} / \mathrm{kap} / \mathrm{hari}$

d). Indikator untuk mengukur tingkat keanekaragamandan keseimbangankonsumsi pangan, yang juga merupakan indikator kualitas konsumsi panganadalah dengan skor Pola Pangan Harapan (PPH). Menurut Hardinsyah (2002), dengan pendekatan PPH dapat dinilai mutu pangan penduduk berdasarkan skorpangan (dietary score). Semakin tinggi skor mutu pangan, mengindikasikansituasi pangan yang semakin beragam dan semakin baik komposisi dan mutugizinya.Tingkat mutu Pola Konsumsi Pangan masyarakat Sulut masih belum beragam, bergizi dan seimbang.Hal ini ditunjukkan dari skor $\mathrm{PPH}$ baru sebesar 89,8 atau kurang dari skor PPH ideal sebesar 100. Lebih jelas dapat dilihat pada Tabel 3.

Selanjutnya kontribusi masingmasing kelompok pangan maupun beberapa komoditas penting dapat diuraikan sebagai berikut :

\section{- Padi- padian}

Konsumsi terhadap kelompok pangan padi-padian menyumbangkan energi sebesar $1166,9 \mathrm{kkal}(57,7 \%)$ dari total energi 2,021

kkalmelebihi jumlah konsumsi yang dianjurkan sebesar 1.000 kkal (WNPG,
2004). Bahan pangan beras memberikan kontribusi terbesar yaitu 1111,4 kkal, selanjutnya terigu 46,8 kkal, dan jagung 8,6 kkal. Padi-padian didominasi beras yang merupakan menu pokok masyarakat Sulawesi Utara . Budaya makan nasi bangsa Indonesia terlihat disaat makan yakni nasi diambil pertama menyusul lauk dan sayuran (Sumarno,2016). Beberapa ciri budaya makan antara lain:

1. Nasi menjadi komponen utama dalam porsi besar.

2. Nasi menjadi sumber energi dan protein

3. Lauk seperti ikan, daging, sayur, tempe, dan telur menjadi komponnen kedua dalam porsi kecil

4. Nasi dikonsumsi 2 smpai 3 kali setiap hari

5. Umumnya setiap orang belum makan kalau belum makan nasi

6. Makan nasi dan lauk sampai kenyang adalah skala prioritas, selanjutnya baru makan makanan lainnya.

7. Bahan pangan sumber energi alternatif sulit menggantikan nasi selama masih tersedia. 
- Umbi-umbian

Konsumsi Kelompok Pangan umbiumbian memberikan kontribusi energi sebesar 64,5 kkal (3,2\%) dari total konsumsi energi sebesar 2,021 kkal. Dimana, energi tersebut berasal dari bahan pangan ketela pohon 34,9 kkal, Ubi jalar 16,8 kkal, Sagu 3,5 kkal, dan Talas 5,5 kkal, serta kentang 3,9 kkal. Total konsumsi energi Kelompok Pangan umbi-umbian masyarakat Sulawesi Utara sebesar 64,5 kkal masih dibawah standar konsumsi energi yang dianjurkan sebesar 120 kkal (WNPG 2004).

\section{- Pangan Hewani}

Konsumsi pangan masyarakat Sulawesi Utara pada Kelompok Pangan Hewani menyumbangkan energi sebesar 212,9 kkal atau $10,5 \%$ dari total konsumsi energi 2,021 kkal, yang berarti konsumsi tersebut masih lebih rendah bila dibandingkan dengan konsumsi energi Kelompok pangan hewani yang dianjurkan dalam WNPG 2004 sebesar 240 kkal. Hasil ini jauh dibawah konsumsi penduduk DKI Jakarta yang sudah mmencapai skor ideal 24 untuk pangan hewani (Anggoro,2015).Selanjutnya bahan pangan ikan memberikan kontribusi terbesar yaitu 143,1 kkal, selanjutnya daging ternak ruminansia/besar $(25,7 \mathrm{kkal})$, telur $(18,7$ kkal), susu (15,1 kkal) dan daging unggas (10,4 kkal).

\section{- Minyak dan Lemak}

Konsumsi pangan masyarakat Sulawesi Utara pada Kelompok Pangan minyak dan lemak memberikan kontribusi energi sebesar 256,8 kkal atau $12,7 \%$ dari total konsumsi energi sebesar 2,021 kkal, yang berarti konsumsi tersebut lebih tinggi dibandingkan dengan konsumsi energi kelompok pangan minyak dan lemak yang dianjurkan dalam WNPG 2004 sebesar 200 kkal.

\section{- Buah/Biji Berminyak}

Konsumsi pangan masyarakat Sulawesi Utara terhadap Kelompok Pangan buah/biji berminyak menyumbangkan energi sebesar 28,2 kkal atau $1,4 \%$ dari total konsumsi energi 2,021 kkal, yang berarti konsumsi tersebut masih kurang dari konsumsi energi Kelompok Pangan buah/biji berminyak yang dianjurkan dalam WNPG
2004 sebesar 60 kkal.Selanjutnya hasil survey juga menunjukkan bahwa pada Kelompok Pangan ini konsumsi buah kelapa memberikan kontribusi terbesar yaitu 24,9 kkal, kemiri 2,3 kkal, biji jambu mete 0,9 kkal dan melinjo 0,2 kkal.

\section{- Kacang-kacangan}

Konsumsi pangan masyarakat Sulawesi Utara terhadap Kelompok Pangan kacang-kacangan menyumbangkan energi sebesar 51,3 kkal atau 2,5\% dari total konsumsi energi 2,021 kkal, yang berarti konsumsi tersebut masih lebih rendah dari konsumsi energi Kelompok Pangan kacangkacangan yang dianjurkan dalam WNPG 2004 sebesar 100 kkal.

Selanjutnya hasil survey juga menunjukkan bahwa konsumsi bahan pangan kacang kedelai memberikan kontribusi terbesar yaitu 28,3 kkal, diikuti kacang tanah dan kacang merah masingmasing 10,8 kkal dan 8,5 kkaldan kacang hijau 3,7 kkal.

\section{- Gula}

Konsumsi pangan masyarakat Sulawesi Utara terhadap kelompok pangan gula menyumbangkan energi sebesar 42,0 kkal atau 2,1\% dari total konsumsi energi, yang berarti konsumsi tersebut dibawah konsumsi energi kelompok pangan gula yang dianjurkan dalam WNPG 2004 sebesar 100 kkal.

Selanjutnya hasil survey juga menunjukkan bahwa konsumsi gula pasir memberikan kontribusi sebesar yaitu 38,8 kkal, sementara gula aren hanya sebesar 2,6 kkal.

\section{- Sayur dan Buah}

Konsumsi pangan masyarakat Sulawesi Utara terhadap kelompok pangan sayur dan buah menyumbangkan energi sebesar $171,0 \mathrm{kkal}$ atau $8,5 \%$ dari total konsumsi energi, yang berarti konsumsi tersebut melebihi total konsumsi energi kelompok pangan sayur dan buah yang dianjurkan dalam WNPG 2004 sebesar 120 kkal.

Selanjutnya hasil survey juga menunjukkan bahwa buah-buahan memberikan kontribusi lebih besar dibandingkan dengan sayursayuran, yaitu 95,5 kkal dibandingkan dengan sayuran 75,5 kkal. 


\section{- Lain-lain}

Konsumsi pangan masyarakat Sulawesi Utara terhadap kelompok pangan lain-lain menyumbangkan energi sebesar 27,5 kkal atau $1,4 \%$ dari total konsumsi energi, yang berarti konsumsi tersebut kurang dari konsumsi energi kelompok lainlain yang dianjurkan dalam WNPG 2004 sebesar $60 \mathrm{kkal}$.

Hubungan antara Karakteristik Keluarga dengan Angka Kecukupan Energi (AKE) dan Angka Kecukupan Protein (AKP) RumahTangga.

rumah $\begin{gathered}\text { Hubungan antara pendidikan ibu } \\ \text { tangga }\end{gathered}$ kecukupanenergi (AKE) menunjukkan tidak terdapat hubungan yang signifikanantara pendidikan ibu rumah tangga dengan AKE rumah tangga. Demikian halnya pendidikan ibu rumah tangga dengan tingkat kecukupan protein (AKP) rumah tangga tidak terdapat hubungan yang signifikan .Hasil penelitian Bambang (2012) melaporkan bahwa tingkat pendidikan ibu rumah tangga tidak berpengaruh nyata terhadap tingkat kecukupan gizi rumah tangga. Dalam kenyataannya,walaupun ibu berpendidikan tinggi akan memiliki kemampuan dalam menyerap informasi gizi sehingga dapat menyusun menu makanan yang baik bagi perbaikan gizi keluarga,namun karena sebagian besar anggota rumah tangga mempunyai aktivitas di luar rumah baik sebagai pelajar maupun pekerja sehingga masing-masing individu memiliki keputusan sendiri dalam memilih menu makanan yang dikonsumsinya.

Menurut Hardinsyah (2007), ada lima faktor yang diduga merupakan determinan penting individu dalam memilih konsumsi pangan yang beragam yaitu daya beli, pengetahuan gizi, waktu yang tersedia untuk pengelolaan pangan, kesukaan pangan dan ketersediaan pangan. Hubungan antara jumlahr keluarga dangan tingkat kecukupan energi (AKE) rumah tangga menunjukkan tidak terdapat hubungan yang antara pendidikan besar keluarga dengan AKE rumah tangga. Begitu pula antara jumlah keluarga dengan tingkat kecukupan protein (AKP) rumah tangga menunjukkan tidak terdapat hubungan yang signifikan. Dalam hal ini karena sebagian besar anggota rumah tangga mempunyai aktivitas dan menghabiskan waktunya diluar rumah baik sebagai pelajar maupun bekerja mencari nafkah sehingga masingmasing individu memiliki keputusan sendiri dalam memilih menu makanan yang dikonsumsinya. Menurut Suryana (2008), konsumsi pangan yang beraneka ragam dan seimbang dipengaruhi oleh banyak faktor, antara lain faktor internal (individu) seperti pendapatan, preferensi, budaya dan religi serta pengetahuan gizi. Sedangkan faktor eksternal seperti produksi, ketersediaan dan distribusi. Hubungan antara pengeluaran pangan rumah tangga dangan tingkat kecukupan energi (AKE)menunjukkan tidak terdapat hubungan yang signifikan. Begitu pula hubungan antara pengeluaran pangan rumah tangga dengan tingkat kecukupan protein (AKP) rumah tangga menunjukkan tidak terdapat hubungan yang signifikan Menurut Nilasari (2012), proporsi pengeluaran pangan rumah tangga berkorelasi negatif dengan pendapatan artinya alokasi pengeluaran untuk pangan akan semakin kecil dengan bertambahnya pendapatan rumah tangga, karena sebagian besar dari pendapatan tersebut dialokasikan pada kebutuhan non pangan. Besarnya biaya pangan tidak hanya bergantung pada besarnya pendapatan rumah tangga tapi juga bergantung pada pengetahuan gizi penentu pembelian pangan (ibu rumahtangga/kepala keluarga) dan komposisi anggota rumahtangga (Hardinsyah 2007).

Bagi masyarakat Indonesia, beras merupakan sumber karbohidrat yang secara sosial-ekonomi lebih patut; sedangkan ubi, singkong, sagu, dan umbi-umbian lainnya diposisikan sebagai sumber karbohidrat yang status sosialnya lebih rendah (baca: makanan orang miskin). Alternatif sumber karbohidrat yang diterima masyarakat Indonesia secara luas adalah gandum dan kentang, karena jenis sumber karbohidrat ini diasosiasikan dengan pangan masyarakat maju, diimpor dari negara maju. Ironisnya, lahan yang cocok untuk budidaya gandum atau kentang di Indonesia sangat terbatas. Klasifikasi pangan pokok yang diasosiasikan dengan status sosial ekonomi ini sesungguhnya yang menjadi ganjalan program diversifikasi pangan di Indonesia. . Rata-rata masyarakat Sulawesi Utara mengkonsumsi bahan pangan disajikan pada Tabel 4. 
Tabel 4.Rata-rata Komsumsi bahan Pangan/Hari/Tahun/Kapita masyarakat Sulawesi Utara, Tahun 2017

\begin{tabular}{lll}
\hline No & Jenis Bahan Pangan & Konsumsi/Hari/Tahun/Kapita \\
\hline 1 & Beras & 308,7 gram, setara dengan $112,7 \mathrm{~kg}$ per tahun. \\
\hline 2 & Ketela pohon & 31,8 gram, setara dengan $11,6 \mathrm{~kg}$ per tahun. \\
\hline 3 & Ubi jalar & 15,9 gram, setara dengan $5,8 \mathrm{~kg}$ per tahun. \\
\hline 4 & Talas & 6,6 gram, setara dengan $2,4 \mathrm{~kg}$ per tahun. \\
\hline 5 & Kentang & 5,5 gram, setara dengan $2,0 \mathrm{~kg}$ per tahun \\
\hline 7 & Sagu & 1,0 gram, setara dengan $0,4 \mathrm{~kg}$ per tahun. \\
\hline 8 & Buah-buahan & 184,2 gram, setara dengan $67,2 \mathrm{~kg}$ per tahun. \\
\hline 9 & Sayur-sayuran & 295,3 gram, setara dengan $107,8 \mathrm{~kg}$ per tahun. \\
\hline 10 & Susu & 158,3 gram, setara dengan $57,8 \mathrm{~kg}$ per tahun \\
\hline 11 & Telur & 24,7 gram, setara dengan $9,0 \mathrm{~kg}$ per tahun \\
\hline 12 & Daging & 12,8 gram, setara dengan $4,7 \mathrm{~kg}$ per tahun. \\
\hline 13 & Unggas & 12,4 gram, setara dengan $4,5 \mathrm{~kg}$ per tahun. \\
\hline 14 & Gula pasir & 5,9 gram, setara dengan $2,2 \mathrm{~kg}$ per tahun \\
\hline 15 & Minyak Kelapa & 10,7 gram, setara dengan $3,9 \mathrm{~kg}$ per tahun \\
\hline 16 & Minyak Sawit & 21,1 gram, setara dengan $7,7 \mathrm{~kg}$ per tahun. \\
\hline 17 & Kacang Tanah & 8,1 gram, setara dengan $3,0 \mathrm{~kg}$ per tahun. \\
\hline 18 & Kacang Hijau & 2,4 gram, setara dengan $0,9 \mathrm{~kg}$ per tahun. \\
\hline 19 & Kacang Kedele & 1,1 gram, setara dengan $0,4 \mathrm{~kg}$ per tahun \\
\hline & & 8,5 gram, setara dengan $3,1 \mathrm{~kg}$ per tahun \\
\hline
\end{tabular}

\section{Proyeksi Penyediaan Pangan}

$\begin{array}{cccc} & \text { Pada Tabel } 4 & \text { menyajikan } & \text { secara } \\ \text { spesifik } & \text { konsumsi } & \text { beras } & 112.7\end{array}$ $\mathrm{kg} /$ kapita/tahun, angka ini belummenyentuh dibawah 100. Walaupun selang 5 tahun terakhir ada kencenderungan menurun dari $130 \mathrm{~kg} / \mathrm{kapita} /$ tahun pada tahun 2012 (BPS,2016) menjadi $112.7 \quad \mathrm{~kg} / \mathrm{kapita} / \mathrm{tahun}$ ditahun 2017. Ditingkat nasional terjadi penurunan konsumsi beras ( Erwidodo,2016) bahkan sampai menyentuh angka dibawah 100. .Meski tingkat konsumsi beras mengalami penurunan, tetapi tingkat partisipasi konsumsi masyarakat meningkat,hal ini berarti banyak penduduk yang tadinya tidak mengkonsumsi beras sebagai pangan pokok beralih mengkonsusmsi beras.Beberapa komoditi pangan local yang sebelumnya menjadi bahan pangan pokok diwilayah Indonesia Timur, tingkat konsumsi dan partisipasi konsumsinya cenderung menurun digantikan oleh beras. Hal ini dapat dijadikan acuan dan dijadikan bahan koreksi total bahwa program diverifikasi pangan tidak berhasil bahkan gagal. Kemungkinan yang menjadi penyebab meningkatnya kebutuhan beras nasional karena keinginan masyarakat untuk mengkonsumsi pangan lokal, seperti ubijalar, talas, dan pangan lokal lainnya sebagai pangan alternatif sumber karbohidrat, terkendala dari segi harga relatif mahal dan tidak selalu tersedia saat dibutuhkan.

\section{KESIMPULAN DAN SARAN}

\section{Kesimpulan}

1. Konsumsi pangan masyarakat Sulawesi Utara berada diatas Angka Kecukupan Energi Ideal sebesar 2.000 kkal/kapita/hari, yakni sebesar $2.021 \mathrm{kkal}$ perkapita perhari., termasuk dalam kategori normal $(90-<120 \% \mathrm{AKE} / \mathrm{G})$.

2. Kelompok Pangan padi-padian menyumbangkan energi paling besar yaitu 1166,9 kkal perkapita per hari (58,3 \% dari angka kecukupan energi), diikuti Minyak dan Lemak 256,8 kkal ( $12,8 \%)$, Pangan Hewani 212,9 kkal (10,6 $\%$, sayur dan buah 171,0 kkal $(8,5 \%)$ dan Umbi-umbian sebesar 64,5 kkal (3,2 $\%$ ), sedangkan Kelompok Pangan Buah/Biji Berminyak dan Kelompok Pangan Lain-lain menyumbangkan 
energi paling kecil, masing-masing yaitu 28,2 kkal ( 1,4\%), dan 27,5 kkal (1,4\%).

3. Konsumsi protein masyarakat Sulawesi Utara mencapai 57,5 Gram/Kapita/Hari. Jika dibandingkan dengan Angka Kecukupan Protein sebesar 52,0 Gram/Kapita/Hari maka Tingkat Konsumsi Protein telah mencapai 110,5 $\%$ AKP.Pola Konsumsi Pangan masyarakat masih belum beragam, bergizi dan seimbang. Hal ini ditunjukkan dari skor PPH baru sebesar 89,8 atau kurang dari skor PPH ideal sebesar 100.

4. Aspek sosial ekonomi yang meliputi tingkat pendidikan, jumlah anggota rumah tangga, dan pendapatan rumah tangga menunjukkan tidak terdapat hubungan yang signifikan terhadap tingkat kecukupan gizi (AKE dan AKP).

\section{Saran}

Meningkatkan diseminasi promosi kesehatan mengenai Pedoman Gizi Seimbang (PGS) kepada masyarakat, khususnya mengkonsumsi makanan yang beragam, berimbang dan bergizi sesuai sesuai standar kebutuhan agar dapat hidup sehat, aktif danproduktif.

Mencari dan mengembangkan serta mempromosikan sumber karbohidrat lainnya selain beras terutama jenis umbi-umbian lokal yang potensial, strategis dan prospektif dalam rangka meningkatkan skor PPH.

\section{DAFTAR PUSTAKA}

Ariani. 2006. Penguatan Ketahanan Pangan Daerah Untuk Mendukung KetahananPangan Nasional.Pusat Analisis Sosial Ekonomi dan Kebijakan Pertanian. Departemen Pertanian. Jakarta.

Anwar, K. dan Hardinsyah. 2014. Konsumsi Pangan dan Gizi serta Skor Pola Pangan Harapan (PPH) pada usia 19-49 tahun di Indonesia. Jurnal Gizi dan Pangan. Jakarta..

Anggoro, A. 2015. Analisis Konsumsi Pangan Penduduk Provinsi DKI Jakarta. Tesis, IPB. Bogor.

\section{Badan Ketahanan Pangan Kementerian Pertanian. 2012b. Roadmap Diversifikasi Pangan 2011-2015. Jakarta.}

Badan Litbang Pertanian. 2012. Pedoman Umum MKRPL. Balitbangtan Jakarta.

Badan Pusat Statistik. 2010a. Perkembangan Beberapa Indikator Utama SosialEkonomi Indonesia - Agustus 2010. Badan Pusat Statistik, Jakarta.

Broto ,W. 2012. Pemanfaatan Pangan Lokal Untuk Penganekaragaman Konsumsi Pangan. Balai Besar Penelitian dan Pengembangan Pasca Panen Pertanian

Budiarjo, T. 2008. Pengaruh Terhadap Penurunan Zat Gizi, Senyawa Fenolik, Antisian dan Aktivits Antioksidan Rendah. Magister Gizi Masyarakat. Universitas Diponegoro.http//magi.undip.ac.id; diakses 01 Oktober 2009.

Bambang, J..S., M. Nabiu, dan Sugiarti.2012. Faktor-faktor yang Mempengaruhi Tingkat Kecukupan Gizi Mandiri Pangan. Jurnal Program Studi Agribisnis Fakultas Pertanian Universitas Bengkulu.

Calverley, D.J.B. 1994. Programme for the Prevention of Food Losses: a Study of Eleven Projects in Asia concerned with Rice. Final Report. Food and Agriculture Organization, Rome.

Dinas Pertanian,2015. Laporan Tahunan Dinas Pertanian Sulawesi Utara.

Damanik, R., I. Ekayanti, D. Hariyadi. 2010. Analisis Pengaruh Pendidikan Ibu Terhadap Status Gizi Balita di Propinsi Kalimantan Barat. Jurnal Gizi dan Pangan. Jakarta.

Erwidodo. $2016 . \quad$ Meningkatkan Ketersediaan dan Keterjangkaun Pangan Lokal Menuju Ketahanan Pangan dan Nutrisi. Dalam E. Pasandaran, R. Heriawan, dan M. Syakir (eds). Pangan Lokal, Budaya, Potensi dan Prospek Pengembangan. IAARD Press Jakarta. 
Hardinsyah, A. Irawati, D, Kartono, S, Prihartini,I. Linorita, L. Amilia L, M. Fermanda , E. Adyas ,D. Yudianti , C. Kusrto danY. Heryanto ,2012. Pola Konsumsi Pangan dan Gizi Penduduk Indonesia.Departemen Gizi Masyarakat FEMA IPB dan Badan Litbangkes Kemenkes RI. Bogor.

Hardinsyah, 2007. Review Faktor Determinan Keragaman Konsumsi Pangan. Jurnal Gizi dan Pangan. Jakarta.

Hariyadi, P., D. Martianto, B, Arifin, B, Wijaya, and Winarno, FG.,2006. Reconstruction OfSocial Institutions For Prevention And Handling Of Food Insecurity And Malnutrition (InBahasa Indonesia). Proceedings Lokakarya Nasional II Penganekaragaman Pangan). Forum Kerja Penganekaragaman Pangan PT. Jakarta: ISM Bogasari Flour Mills.

Joseph G. H.2015. Model Kawasan Rumah Pangan Lestari(MKRPL) SULUT. Prosiding BPTP SULUT.

Manesa J., F.Y. Baliwati, I. Tanziha. 2008. Ketahanan Pangan Rumah tangga di Desa Penghasil damar. Kab.Lampung Barat. Jurnal Gizi dan Pangan. Jakarta

Nilasari, A., M. Harisudin, dan Widiyanto. 2012. Analisis Hubungan Antara Pendapatan dan Proporsi Pengeluaran Pangan dan Kecukupan Gizi Rumah tangga. Jurnal Gizi dan Pangan. Jakarta.
Sugiono, 2008. Metode Penelitian Kuantitatif, Kuaitatif dan R\&D. Penerbit Alfa Beta Bandung.

Sumarno. 2010. Masalah Pokok Kecukupan Produksi Tanaman Pangan dan Kebutuhan Teknologi. Bahan FGD Kementerian Riset dan Teknologi. Jakarta, 15 September 2010.

Suryana, 2012.Program dan Kegiatan Badan Ketahanan Pangan 2013 Mendukung Kegiatan Diversifikasi Konsumsi Pangan .Disampaikan pada Acara Musyawarah Perencanaan Pembangunan Pertanian (Musrembangtan 2012).Jakarta 23 Mei 2012.

Tanziha dan Herdiana. 2009. Analisis Jalur Faktor-faktor yang Mempengaruhi Ketahanan Pangan Rumah tangga di Kab. Lebak. Banten. Jurnal Pangan dan Gizi. Jakarta.

Widyakarya Nasional Pangan dan Gizi VIII[WNPG]. 2004. Angka Kecukupan Gizi dan Acuan Label Gizi. Jakarta (ID). Direktorat Standarisasi Produk Pangan. 